Received: 02 April 2018

Revision Received: 10 December 2018

Copyright $\odot 2019$ ESTP

Accepted: 07 February 2019

www.estp.com.tr

DOI 10.12738/estp.2019.2.001 • April 2019 • 19(2) •3-21

Article

\title{
The Structural Relationship among Digital Literacy, Learning Strategies, and Core Competencies among South Korean College Students
}

\author{
Kyu Tae Kim \\ Keimyung University, Korea
}

\begin{abstract}
This study explores the structural relationship among digital literacy, learning strategies, and core competencies among South Korean college students as well as the group differences between these variables depending on individual characteristics. Data analysis was conducted by correlation analysis, independent sample $t$-testing, and structural equation modelling. Participants were 916 college students from 10 colleges in South Korea. The results showed that i) no difference between groups existed in digital literacy and core competencies; however, a group difference existed in learning strategy; ii) digital literacy had a direct effect on core competencies and learning strategies had an indirect effect on the influence of digital literacy on core competencies; and iii) digital literacy can enhance the effect of core competencies when mediating learning strategy. This study suggests areas for future research, including developing digital technology-enhanced, competency-driven learning resources that account for the effects of cognitive, metacognitive, and resource management; the relationship between digital literacy and core competencies of learner characteristics such as achievement goal orientation, learning style, and academic self-efficacy; the effect of individual digital technologies on core competencies based on individual learning strategies through experimental and quasiexperimental designs; and qualitative studies on employing digital technologies and learning strategies.
\end{abstract}

\section{Keywords}

Digital Literacy $\bullet$ Core Competency $\bullet$ Learning Strategy $\bullet$ Motivated Strategies for Learning Questionnaire $\bullet$ Korean College Student

This research was supported by the Bisa Research Grant of Keimyung University in 2016.

Correspondence to: Kyu Tae Kim, Associate Professor, Keimyung University, Korea. Phone: 82-010-9774-5311. Email: gtkim424@kmu.ac.kr

Citation: Kim, K. T. (2019). The Structural Relationship among Digital Literacy, Learning Strategies, and Core Competencies among South Korean College Students. Educational Sciences: Theory \& Practice, 19(2), 3-21. http://dx.doi.org/10.12738/estp.2019.2.001 


\section{Background}

Schwab (2016) coined the term Fourth Industrial Revolution and characterized it as being hyperconnected by the Internet of Things (IoT) or being hyper-intelligent owing to big data or artificial intelligence. A digital-based, knowledge-based society is demanding new future capabilities. South Korea's government is strengthening digital literacy programs, including learning analysis platforms and software education, so that college students can cope with the demands of the Fourth Industrial Revolution (Ministry of Science and ICT, 2017). South Korea's colleges have emphasized technology-enhanced curricula and programs based on big data, augmented reality (AR), virtual reality (VR), and the IoT in the era of the Fourth Industrial Revolution (Ministry of Education, 2018).

It is inevitable for college students to have digital literacy, including an ability not only to use digital technologies but also to navigate information and knowledge for meaningful learning and academic performance in the digitalized environment (Calvani, Fini, Ranieri, \& Picci, 2012; Howland, Jonassen, \& Marra, 2012). Sozdamar-Keskin, Ozata, Banar, and Royle (2015) defined digital literacy as actively participating in educational, social, and vocational life by having the ability to use digital learning tools, manage the digital learning platforms, and use advanced-level digital tools securely and ethically.

Digital literacy has a significant influence both on college students' core competencies and on future job performance requiring digital technology-enhanced knowledge and skills (Knight, 2011; Pirzada \& Khan, 2013; Vrana, 2016). Core competency is defined as the cognitive, affective, and social skills that learners need to ensure success and competitive advantage in the present or near future of their educational and professional lives (Boyatzis, 2008; Boyatzis \& Saatcioglu, 2008). Cognitive skills are linked to college major knowledge base and to critical and creative thinking abilities (Billing, 2007). Emotional skills are related to the ability to understand and manage the self, understand others' emotions, and demonstrate empathy (Wang, Young, Wihite, \& Marczykm, 2011). Social skills are connected to collaboration, communication, and participation among others (Boyatzis, 2009). Core competencies of college students are based on hard skills related mainly to cognitive skills and academic major knowledge, and soft skills linked with non-cognitive skills including problem solving, communication, self-development, and management (Adams, 2013). Garner (2010) argued that when emotional skills are associated with cognitive abilities, college students' learning and job skills may be improved. Magno (2010) identified the role of meta-cognitive skills in developing critical thinking ability.

Recently, some scholars have argued that digital literacy is not merely about the ability to make effective use of digital tools and information (Ala-Mutka, 2011; Cartelli, 2010; Ferrari, 2012). They have expanded the concept of digital literacy to include the essential capabilities of social participation, effective collaboration and communication, critical thinking, and problem-solving by using digital technologies and information (Cartelli, 2010; Martin \& Grudziecki, 2006). They have also considered that digital literacy may in fact be a set of core competencies. Digital literacy has in fact been identified by scholars as a catalyst or an accelerator for core competencies in that it may help to solve problems effectively, facilitate communication and collaboration with others, manage and share information, create knowledge, think critically, and participate positively in social activities using digital devices and skills (Cartelli, 2010).

This study regards digital literacy as a tool or means to promote core competencies. SevillanoGarcía and Vázquez-Cano (2015) identified the role played by digital mobile devices in catalyzing generic competencies in a college context. Howland, Jonassen, and Marra (2012) argued that digital technologies function as a tool to facilitate information exploration and organization, a contextual tool that supports learning experiences and situational experiences, an intermediary tool for communicating, and a reflective tool that stimulates critical thinking and meta-cognition. Gardner and Davis (2013) noted that applications 
are an effective tool for learners who are digital natives to express their identity, connect and communicate with others, and form creative ideas. Solomon and Schrum (2007) pointed out that learning technologies, including Web 2.0, encourage students to explore information, engage in immediate interaction, and collaborate to strengthen the 21 st century skills, or core competencies.

In this study, digital literacy was rigorously defined as the ability to use digital technologies, to navigate, collect, analyze, and evaluate the information and knowledge, to construct new information, to create digital expressions, and to communicate with others both during the learning process and while performing one's job. However, it is not easy to find previous empirical studies that see digital literacy as a sub-variable of core competence. Also, it is not difficult to find that digital literacy may be an independent variable or an influencer of promoting core competencies such as problem-solving ability, critical thinking, and communication (Gallarado-Eschenique, Oliveira, Marques-Molias, \& Esteve-Mon, 2015; Hatlevik \& Christopherson, 2013; Koltay, 2011). In this regard, this study is meaningful in deriving practical knowledge and strategies considering the relationship between the relationship between digital literacy - which is itself related with understanding and competent use of digital technology, Internet platforms, and web networks and information - and core competencies - which are coupled with problem-solving, communication, and collaboration.

College students require appropriate learning skills and techniques to communicate and collaborate with other students as well as to collect, articulate, organize, and express knowledge and information through digital technology and information utilization. It is necessary for them to use the relevant learning strategies - i.e., the cognitive and behavioral skills, methods or techniques for learning in digital-driven, constructive learning environments. Learning strategies include cognitive strategies (e.g., rehearsal, elaboration, organization, critical thinking), meta-cognitive strategies (e.g., planning, monitoring, and regulating strategies), and resource management strategies (e.g., time management, effort management, peer learning, and help-seeking; Garcia \& Pintrich, 1996; Pintrich, Smith, Garcia, \& McKeachie, 1993; Schunk, 2004). These learning strategies are facilitators for students' digital literacy (Dabbagh \& Kitsantas, 2012; Liu, Cheng, \& Huang, 2011). For example, they may benefit from using smart learning devices for efficient preparation of notes, summaries, and presentations to explore and analyze the diversity and wealth of knowledge and information that is available through the Internet. Further, students can collaboratively discuss and solve problems through social media. Jiménez-Cortés, Vico-Bosch, and Rebollo-Catalá (2017) presented a wider variety of independent and collaborative learning strategies attained through more advanced digital skills. Kesici, Sahin, and Akturk (2009) found that cognitive learning strategies affect individuals' attitudes toward and utilization of computers.

Digital literacy may be connected with active and meaningful learning in the classroom, in developing and communicating effective learning materials, and in facilitating communication, cooperation, and advice with learners (Davies, 2011; Howland, Jonassen, \& Marra, 2012; International Society for Technology in Education, 2007). Jonassen (1999) presented Constructivist Learning Environments contributing on facilitating a cognitive learning process that enables learners to solve problems effectively by providing both appropriate learning problem situations, examples, and information, and also collaborative tools that encourage learners to share knowledge and information. It is useful to provide students with advanced organizers such as charts, diagrams, images, and videos that match the contents to be taught in the classroom, as these materials help to connect students' pre-existing knowledge with new knowledge that can be further elaborated, organized, and visualized (Ausubel, 2000). In addition, they can produce and provide personalized and customized learning materials through YouTube, TED, and Massive Open Online Courses (MOOCs) along with various indirect experiences, experiments, and exercises using 
simulations or virtual reality techniques. They can then use Facebook, Instagram, Google Docs and Google questionnaires, e-mail, and blogs to facilitate communication, discussion, and feedback with learners (Davies, 2012; Ryan, Magno, \& Sharp, 2011).

Learning strategies may play an important role in cultivating core competencies such as learning and project performance (Alexiou \& Paraskeva, 2010; Kauffman, Zhao, \& Yang, 2011), problem-solving (Cerezo et al., 2010), and teamwork and collaboration (Dabbagh \& Kinsantas, 2012; Järvelä \& Järvenoja, 2011; Lee \& Tsai, 2011). Core competencies can be transferred by the learning strategy used in the learning process of college students (Lee \& Choi, 2015; Whitston, 1998). For example, inference and logical thinking enhance self-examination and reflection practices, and meta-cognitive strategies draw on the reflection on and inspection of learning outcomes. Tariq, Scott, Cochrane, Lee, and Ryles (2004) suggested that college students' proficiencies and degree of academic development vary according to the learning skills used in classroom and their own respective individual processes of learning. Billing (2007) specifically addresses the transfer of learning to the core competencies of cognitive learning strategies in the learning process. De Backer, Van Keer, and Valcke (2015) found that college students' meta-cognitive skills were promoted through peer tutoring. English and Kinsantas (2013) stated that the challenges for problem solving and the success of the project are closely related to learning strategies such as monitoring and reflection. In this sense, the learning strategy plays a role in facilitating the transition process that nurtures their learning processes and performances in core competency development.

While there is insufficient prior research on whether learning strategy has a mediating effect of the influence of digital literacy on core competencies, it is possible to use existing research to estimate the impact of the mediating roles of learning strategies in developing core competencies. To illustrate, Azevedo (2005) noted that using web-based or digital technologies to promote meta-cognitive strategies affected the promotion of advanced thinking skills. Cho and Cho (2013) found that the use of self-regulated learning strategies in SNS-based learning facilitated meta-cognition and mutual cooperation in group project implementation. $\mathrm{Wu}$ (2015) suggested that mental and behavioral strategies are effective for self-efficacy and information seeking ability when using social media.

In this regard, it is significant to explore not only whether digital literacy is a necessary means and tool for developing the core competency of college students but also whether learning strategies function as efficient skills in their learning performance related to core competencies. Further, it can help college teachers to plan and provide learning strategies for effective cognitive learning skills and active and meaningful connection, communication, and collaboration with their students in the digital-driven constructive learning environments.

\section{Hypothesis and Structural Model}

College students need to develop core competencies that are appropriate for the knowledge and information society, especially for the Fourth Industrial Revolution. In the digital learning environment, when students use a learning strategy, it is important to consider that the digital devices and applications will promote the development of core competencies. In this regard, this study explored the impact of digital literacy upon and the role of learning strategies on college students' perceptions of core competencies.

In order to ensure the validity and reliability of the relationship between these variables, it is necessary to explore whether college students participating in this study are homogeneous in digital literacy, core competencies, and learning strategies. This study identified the group differences between these variables depending on individual characteristics, such as whether they are two-year or four-year college students, as well as gender. However, there are insufficient prior studies of the group differences among 
digital literacy, learning strategies, and core competencies based on individual backgrounds. However, it is not easy to estimate group differences because of an insufficient and inconsistent prior empirical basis for exploring group difference in Korea. For example, findings of studies on gender differences in perceptions of core competencies are inconsistent. Baek (2013) stated that there were no gender differences. Some studies reported there were gender differences depending on the sub-variables of core competencies (Hong, Jo, \& Park, 2015; Kang, Kim, Yu, \& Kim, 2014). The gender differences in learning strategies vary depending on the types of learning strategy (Lee, 2015). It is difficult to find related prior studies on the differences between these variables depending on whether students attend two-year or four-year colleges. In this regard, this study identifies whether the group being surveyed is homogeneous or heterogeneous because of the general belief that four-year college students may have higher college entrance scores and demonstrate better academic performance than two-year students.

Along with exploring group differences, there are few studies thus far on the direct influence that digital literacy has upon core competencies and learning strategies. Moreover, there has been little research done upon the mediating role of learning strategies on the relationship of digital literacy to core competencies around the world. In this vein, this study attempts to identify the structural relationship among digital literacy, learning, and core competencies among South Korean college students. In fact, this study may be significant in that it explores the ways that learning strategies may serve as mediating variables for the development of core competencies by using digital technologies and information when college students are in the classroom, are engaged in self-study, or are participating in collaborative learning. The structural models and hypothesis of this study are as follows:

H1. There will be a group difference in digital literacy, learning strategies, and core competencies.

H2. Digital literacy will influence perceptions of core competencies.

H3. Learning strategies will mediate the influence of digital literacy on perceptions of core competencies.

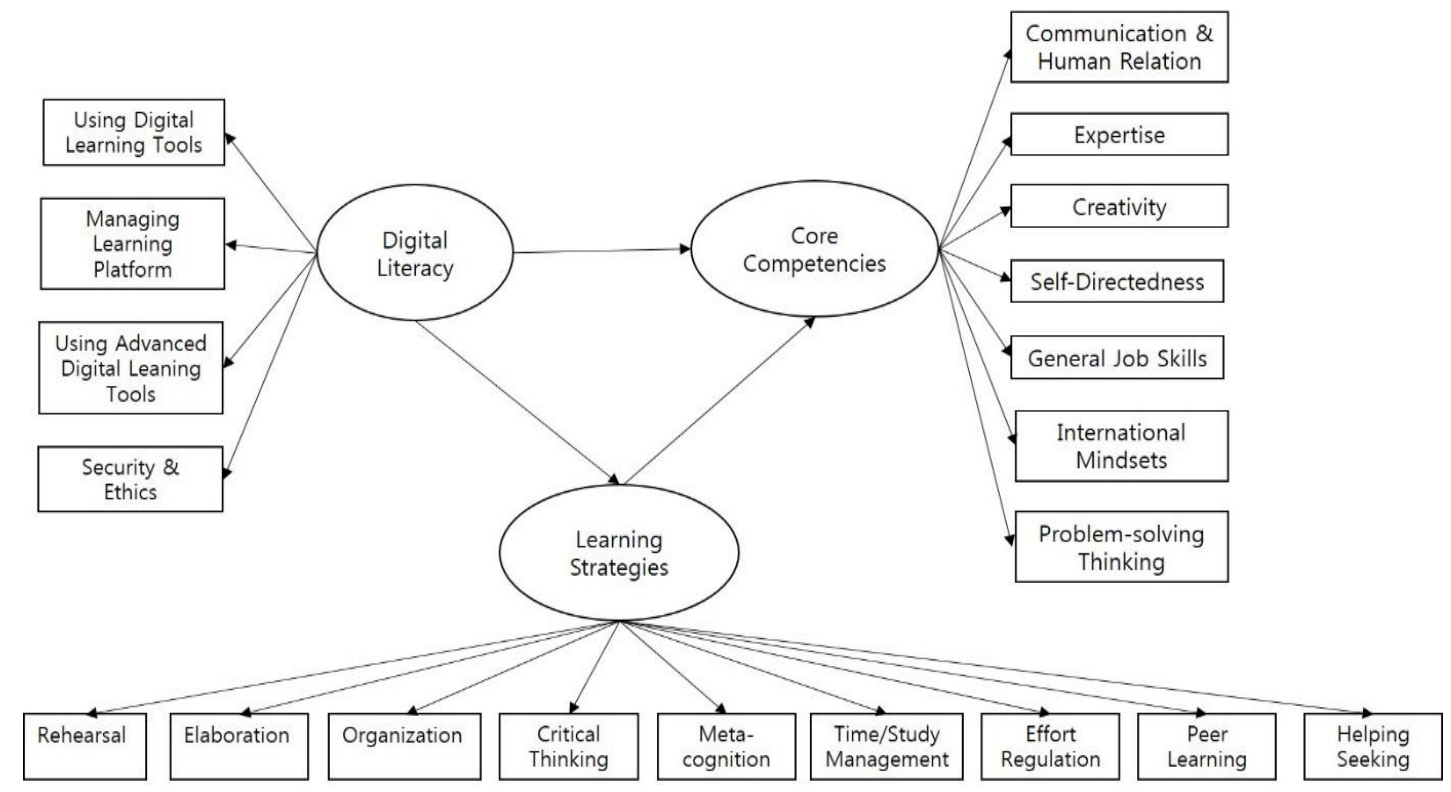

Figure 1. The structural model 


\section{Method}

\section{Participants}

This study applied convenience sampling to members of the target population who met certain practical criteria, such as easy accessibility, geographical proximity, availability at a given time, or the willingness to participate (Etikan, Musa, \& Alkassim, 2016; Farrokhi \& Mahmoudi-Hamidabad, 2012). The sample of this study comprised 916 voluntary participants during the Spring and Fall 2017 semester from 10 universities in the Korean cities of Seoul, Daegu, Cheongju, and Suncheon. Each college student took approximately 20 minutes to complete the questionnaires. The responses of the 916 participants were analyzed as the final dataset. Of these students, 350 were male $(38.2 \%)$ and 566 were female $(61.8 \%)$. The major breakdown was as follows: 389 majored in humanities and social sciences (42.5\%), and 527 were in science and engineering (57.5\%). More than half $(57.4 \%, N=526)$ were enrolled at 4-year colleges and the remainder $(42.6 \%)$ were enrolled at 2-year colleges. Moreover, 320 were at public colleges (34.9\%), and 596 were at private colleges $(65.1 \%)$.

Table 1. Sample of the study

\begin{tabular}{llll}
\hline Participants & & $N$ & $\%$ \\
\hline \multirow{2}{*}{ Gender } & Male & 350 & 38.2 \\
\cline { 2 - 4 } & Female & 566 & 61.8 \\
\hline \multirow{2}{*}{ Major } & Humanities \& Social Sciences & 389 & 42.5 \\
\cline { 2 - 4 } & Science \& Engineering & 527 & 57.5 \\
\hline \multirow{3}{*}{ Type of school } & 4 -year & 526 & 57.4 \\
\cline { 2 - 4 } & 2-year & 390 & 42.6 \\
\cline { 2 - 4 } & Public & 320 & 34.9 \\
\cline { 2 - 4 } & Private & 596 & 65.1 \\
\hline Total & & 916 & 100 \\
\hline
\end{tabular}

\section{Instruments}

The measures formulated in this study were used on the questionnaires validated through original research. It is possible that there is a limitation in assuring the accuracy and objectivity of the measurement because it was a perception or belief of college students about measured variables, and not objectively measured abilities relating to digital literacy, core competencies, and learning strategies. The questionnaires measured in this study are as follows.

Digital literacy was measured using an English self-report scale validated by Sozdamar-Keskin et al. (2015), designed to understand the learners' abilities to use digital tools toward learning. The scale was translated into Korean by the author. As shown in Table 2, there are 22 items in four sub-variables: ability to use digital learning tools, managing digital learning platforms, ability to use advanced level digital tools, and security and ethics. The scales used a 5 -point Likert format $(1=$ strongly disagree to $5=$ strongly agree $)$.

Learning strategies were measured using the Motivated Strategies for Learning Questionnaire (MSLQ), an English self-report instrument designed to measure the cognitive and behavioral skills, methods or techniques used to understand and promote learning and task performance (Pintrich et al., 1991). The MSLQ was translated into Korean by the author. The MSLQ has two sections, Motivation and Learning Strategies, comprising 81 items categorized under 15 different sub-variables. As shown in Table 2, 50 items in nine sub-variables from the Learning Strategies section were utilized for this study. The scales used a 7point Likert format $(1=$ strongly disagree to $7=$ strongly agree $)$. 
Core competencies were measured using a Korean self-report instrument validated by Kim, Chung, Lee, and Yi (2010). The scale was designed to assess Korean college learners' cognitive, affective, and social skills needed to ensure success and competitive advantage in the present or near future in education and professional life. As shown in Table 2, there were 28 items consisting of seven sub-variables. The scales used a 5-point Likert format ( $1=$ strongly disagree to $5=$ strongly agree $)$.

Reliability. The Cronbach's alpha of the measured variables in the original scales and in this study's scales are shown in Table 2. Most items of the subscales in this study were used by the items in original scales and reflected high internal consistency. Further, when compared with the reliability coefficient of the original scale, the reliability of the variables in this study was not found to be significantly higher or lower than that of the original study. However, some items - one in rehearsal (item 46), one in elaboration (item 62), one in peer learning (item 50), and one in help seeking (item 68) under learning strategies - were deleted for increasing these subscale alphas. Most variables except for three - rehearsal (.65), effort regulation (.66), and help seeking (.66) - had coefficients of .70 or higher. The justification for considering these three variables to be accurate follows extant research (Cicchetti, 1994; George \& Mallery, 2003; Nunnally \& Bernstein, 1994; Yu, 2012) which consider .60 to be acceptable.

Table 2. Measured scales and Cronbach's $\alpha$ in this study

\begin{tabular}{|c|c|c|c|c|c|c|}
\hline & \multirow[b]{2}{*}{ Scales } & \multirow[b]{2}{*}{ Example questions } & \multicolumn{2}{|c|}{ Items } & \multicolumn{2}{|c|}{ Cronbach's $\alpha$} \\
\hline & & & $\begin{array}{l}\text { Original } \\
\text { Scale }\end{array}$ & $\begin{array}{l}\text { This } \\
\text { study }\end{array}$ & $\begin{array}{l}\text { Original } \\
\text { Scale }\end{array}$ & $\begin{array}{l}\text { This } \\
\text { study }\end{array}$ \\
\hline \multirow[t]{4}{*}{$\begin{array}{l}\text { Digital } \\
\text { literacy }\end{array}$} & Ability to use digital learning tools & $\begin{array}{l}\text { I can join events on social networks. } \\
\text { I can use applications like Google Docs that are } \\
\text { open for sharing. }\end{array}$ & 5 & 5 & .90 & .85 \\
\hline & $\begin{array}{l}\text { Managing digital learning } \\
\text { platforms }\end{array}$ & $\begin{array}{l}\text { I can upload files (visual or audio) to digital } \\
\text { platforms. } \\
\text { I can form digital objects (figures or digital } \\
\text { designs). }\end{array}$ & 6 & 6 & .92 & .90 \\
\hline & $\begin{array}{l}\text { Ability to use advanced level } \\
\text { digital tools }\end{array}$ & $\begin{array}{l}\text { I can write a QR code and manage it. } \\
\text { I can create an application. } \\
\text { I can act as a moderator in online groups. }\end{array}$ & 7 & 7 & .90 & .83 \\
\hline & Security and ethics & $\begin{array}{l}\text { I know that I have a social responsibility to act in } \\
\text { an ethical way in online platforms. } \\
\text { I know the digital rights of ownership. }\end{array}$ & 4 & 4 & .86 & .85 \\
\hline \multirow[t]{7}{*}{$\begin{array}{l}\text { Learning } \\
\text { strategies }\end{array}$} & Rehearsal & $\begin{array}{l}\text { When I study for this class, I practice saying the } \\
\text { material to myself over and over. } \\
\text { I memorize key words to remember important } \\
\text { concepts in this class. }\end{array}$ & 4 & 3 & .69 & .65 \\
\hline & Elaboration & $\begin{array}{l}\text { I try to relate ideas in this subject to those in other } \\
\text { courses whenever possible. }\end{array}$ & 6 & 5 & .76 & .74 \\
\hline & Organization & $\begin{array}{l}\text { I make simple charts, diagrams, or tables to help } \\
\text { me organize course material }\end{array}$ & 4 & 4 & .64 & .74 \\
\hline & Critical thinking & $\begin{array}{l}\text { Whenever I read or hear an assertion or } \\
\text { conclusion in this class, I think about possible } \\
\text { alternatives. }\end{array}$ & 5 & 5 & .80 & .71 \\
\hline & Meta-cognitive self-regulation & $\begin{array}{l}\text { When I become confused about something I'm } \\
\text { reading for this class, I go back and try to figure it } \\
\text { out on my own. }\end{array}$ & 12 & 12 & .79 & .80 \\
\hline & Time and study environment & $\begin{array}{l}\text { I make good use of my study time for this course. } \\
\text { I attend class regularly. }\end{array}$ & 8 & 8 & .76 & .84 \\
\hline & Peer learning & $\begin{array}{l}\text { When studying for this course, I often try to } \\
\text { explain the material to a classmate or a friend. }\end{array}$ & 3 & 2 & .76 & .71 \\
\hline
\end{tabular}




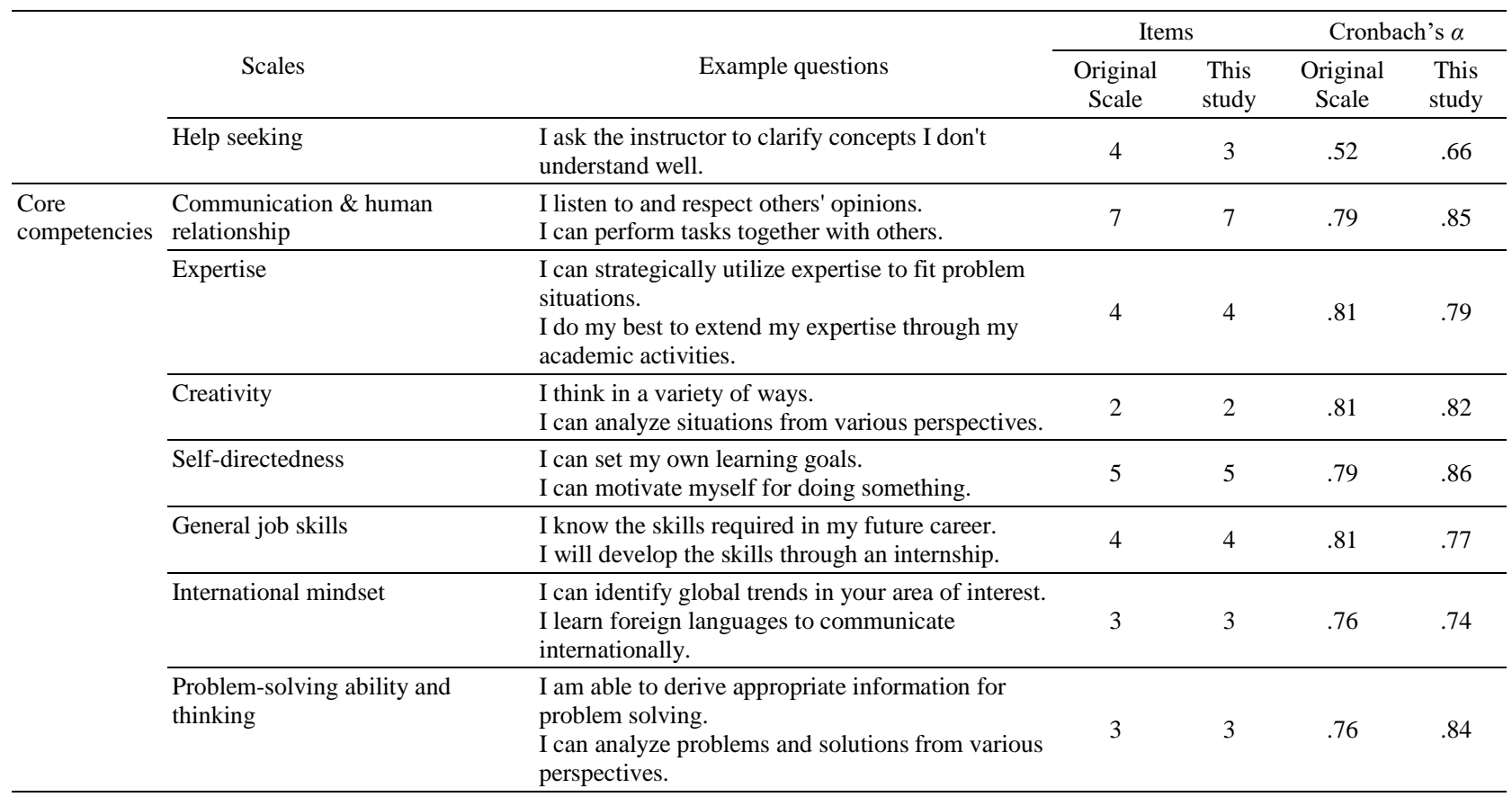

\section{Design and procedure}

This study employed a correlational design conducted in order to assess the relationships that existed between two or more variables by using either a research question or hypothesis. Statistical techniques such as correlation analysis, multiple regression analysis, and structural equation modeling were designed to explore the strengths and directions of the relationships among independent, dependent, and mediating variables. A correlational design was used to examine the measured variables retrospectively at a single point in time by gathering data with commonly used questionnaires mainly comprising closed questions with multiple-choice questions (Fraenkel, Wallen, \& Hyun, 1993; Wood \& Brink, 1998). The author investigated the causal relationship among digital literacy, learning strategies, and core competencies.

\section{Data analysis}

Data analysis for this study yielded Cronbach's $\alpha$ of measured variables. The correlation between the measured variables was analyzed. The independent sample $t$-tests were analyzed for identifying the difference in digital literacy, learning strategy, and core competencies between groups. To perform structural equation analysis, the kurtosis and skewness were checked to verify the normality of the data. For a measurement model, construct validity was assessed by convergent validity and discriminant validity. Convergent validity was assessed by the construct reliability and the Average Variance Extracted (AVE) of the factors in the measurement model. To assess the structural model fit, the following indexes were used: the chi-square statistics and CMIN/df (chi-square divided by the degrees of freedom), goodness-of-fit index (GFI), standardized root mean residual (SRMR), confirmatory fit index (CFI), and root mean square error of approximation (RMSEA) formulated by Kline (2005). Bootstrapping was used to verify the significance of the mediator effect. 


\section{Results}

\section{Descriptive statistics, correlations, and differences between groups}

The assessment of whether a distribution is normal or not depends on its skewness and kurtosis values. According to Kline (2005), if the absolute value of kurtosis is greater than 10 and the absolute value of skew is greater than 3 , it is judged to be in violation of normal distribution. Table 3 shows that the data used in this study were found to be within the normal ranges of skewness and kurtosis in all observed variables. Table 3 shows the results of the correlation between the variables used in this study. Overall, there was a statistically significant correlation between the observed variables at a significance level of .01. As a result of the correlation between the variables, there was no high correlation between all the measured variables of .85 or more (Kline, 2005).

The independent sample $t$-test was analyzed in order to examine group differences in digital literacy, learning strategies, and core competencies. Four-year college students in Korea are generally known to have higher academic achievement and core competencies than two-year college students. In this respect, the mean difference analysis in this study was to explore whether there was a difference in core competence between four-year and two-year college students, that is, whether the groups were homogeneous or heterogeneous. Additionally, this study explored whether gender differences existed among measurement variables.

Table 3. Skewness and kurtosis of measured variables and the correlation between the variables $(N=916)$

\begin{tabular}{|c|c|c|c|c|c|c|c|c|c|c|c|c|c|c|c|c|c|c|c|c|c|c|c|c|c|}
\hline \multicolumn{2}{|c|}{ Variable } & $M$ & $S D$ & Skew & kurtosis & (a) & (b) & (C) & (d) & (e) & (f) & (g) & (h) & (i) & (1) & (k) & (1) & (II) & (I) & (0) & (D) & (q) & (1) & (S) & (t) \\
\hline \multirow{4}{*}{1} & (a) & 3.78 & 0.72 & -0.50 & 0.59 & 1 & & & & & & & & & & & & & & & & & & & \\
\hline & (b) & 3.38 & 0.81 & -0.10 & -0.24 & $.66^{* *}$ & 1 & & & & & & & & & & & & & & & & & & \\
\hline & (C) & 2.98 & 0.75 & 0.11 & 0.13 & $.46^{* *}$ & $.68^{* *}$ & 1 & & & & & & & & & & & & & & & & & \\
\hline & (d) & 3.37 & 0.83 & -0.22 & 0.04 & $.54^{* *}$ & $.62^{* *}$ & $.64^{* *}$ & 1 & & & & & & & & & & & & & & & & \\
\hline \multirow{9}{*}{2} & (e) & 4.23 & 0.81 & 0.06 & 0.27 & $.33^{* *}$ & $.30^{* *}$ & $.18^{* *}$ & $.29^{* *}$ & 1 & & & & & & & & & & & & & & & \\
\hline & (f) & 4.50 & 0.96 & -0.10 & 0.47 & $.30^{* *}$ & $.29^{* *}$ & $.23^{* *}$ & $.35^{* *}$ & $.59^{* *}$ & 1 & & & & & & & & & & & & & & \\
\hline & (g) & 4.65 & 0.99 & 0.05 & 0.33 & $.32^{* *}$ & $.30^{* *}$ & $.25^{* *}$ & $.33^{* *}$ & $.56^{* *}$ & $.65^{* *}$ & 1 & & & & & & & & & & & & & \\
\hline & (h) & 4.50 & 0.91 & -0.08 & 0.76 & $.28^{* *}$ & $.30^{* *}$ & $.24^{* *}$ & $.31^{* *}$ & $.58^{* *}$ & $.63^{* *}$ & $.72^{* *}$ & 1 & & & & & & & & & & & & \\
\hline & (i) & 4.40 & 0.74 & 0.16 & 1.12 & $.28^{* *}$ & $.31^{* *}$ & $.28^{* *}$ & $.33^{* *}$ & $.51^{* *}$ & $.61^{* *}$ & $.65^{* *}$ & $.71^{* *}$ & 1 & & & & & & & & & & & \\
\hline & (1) & 4.82 & 0.88 & 0.10 & 0.34 & $.39^{* *}$ & $.34^{* *}$ & $.20^{* *}$ & $.37^{* *}$ & $.57^{* *}$ & $.64^{* *}$ & $.68^{* *}$ & $.64^{* *}$ & $.67^{* *}$ & 1 & & & & & & & & & & \\
\hline & (k) & 4.87 & 0.95 & -0.26 & 0.26 & $.36^{* *}$ & $.29^{* *}$ & $.17^{* *}$ & $.27^{* *}$ & $.53^{* *}$ & $.55^{* *}$ & $.59^{* *}$ & $.59^{* *}$ & $.54^{* *}$ & $.70^{* *}$ & 1 & & & & & & & & & \\
\hline & (1) & 4.96 & 1.10 & -0.14 & -0.08 & $.26^{* *}$ & $.21^{* *}$ & $.10^{* *}$ & $.22^{* *}$ & $.44^{* *}$ & $.45^{* *}$ & $.56^{* *}$ & $.52^{* *}$ & $.53^{* *}$ & $.67^{* *}$ & $.60^{* *}$ & 1 & & & & & & & & \\
\hline & (ii) & 4.75 & 1.03 & 0.06 & 0.32 & $.31^{* *}$ & $.29^{* *}$ & $.23^{* *}$ & $.30^{* *}$ & $.47^{* *}$ & $.58^{* *}$ & $.63^{* *}$ & $.60^{* *}$ & $.62^{* *}$ & $.71^{* *}$ & $.62^{* *}$ & $.59^{* *}$ & 1 & & & & & & & \\
\hline \multirow{7}{*}{3} & (n) & 3.89 & 0.53 & -1.00 & 5.18 & $.33^{* *}$ & $.23^{* *}$ & $.15^{* *}$ & $.22^{* *}$ & $.50^{* *}$ & $.32^{* *}$ & $.34^{* *}$ & $.27^{* *}$ & $.25^{* *}$ & $.33^{* *}$ & $.34^{* *}$ & $.23^{* *}$ & $.28^{* *}$ & 1 & & & & & & \\
\hline & (0) & 3.32 & 0.70 & -0.30 & 0.66 & $.26^{* *}$ & $.31^{* *}$ & $.29^{* *}$ & $.27^{* *}$ & $.37^{* *}$ & $.36^{* *}$ & $.40^{* *}$ & $.37^{* *}$ & $.34^{* *}$ & $.35^{* *}$ & $.34^{* *}$ & $.26^{* *}$ & $.38^{* *}$ & $.42^{* *}$ & 1 & & & & & \\
\hline & (D) & 3.50 & 0.78 & -0.28 & 0.46 & $.20^{* *}$ & $.25^{* *}$ & $.22^{* *}$ & $.23^{* *}$ & $.34^{* *}$ & $.30^{* *}$ & $.32^{* *}$ & $.31^{* *}$ & $.27^{* *}$ & $.29^{* *}$ & $.26^{* *}$ & $.15^{* *}$ & $.24^{* *}$ & $.44^{* *}$ & $.47^{* *}$ & 1 & & & & \\
\hline & (q) & 3.68 & 0.70 & -0.57 & 1.15 & $.28^{* *}$ & $.29^{* *}$ & $.23^{* *}$ & $.29^{* *}$ & $.43^{* *}$ & $.40^{* *}$ & $.49^{* *}$ & $.40^{* *}$ & $.36^{* *}$ & $.47^{* *}$ & $.39^{* *}$ & $.35^{* *}$ & $.48^{* *}$ & $.51^{* *}$ & $.55^{* *}$ & $.43^{* *}$ & 1 & & & \\
\hline & (1) & 3.44 & 0.67 & $\begin{array}{c}-0.29 \\
\end{array}$ & 0.87 & $.26^{* *}$ & $.28^{* *}$ & $.28^{* *}$ & $.30^{* *}$ & $.34^{* *}$ & $.35^{* *}$ & $.39^{* *}$ & $.37^{* *}$ & $.37^{* *}$ & $.35^{* *}$ & $.35^{* *}$ & $.27^{* *}$ & $.39^{* *}$ & $.46^{* *}$ & $.61^{* *}$ & $.45^{* *}$ & $.58^{* *}$ & 1 & & \\
\hline & (S) & 2.99 & 0.85 & -0.21 & -0.07 & $.20^{* *}$ & $.24^{* *}$ & $.30^{* *}$ & $.28^{* *}$ & $.24^{* *}$ & $.31^{* *}$ & $.28^{* *}$ & $.31^{* *}$ & $.30^{* *}$ & $.23^{* *}$ & $.16^{* *}$ & $.12^{* *}$ & $.22^{* *}$ & $.28^{* *}$ & $.47^{* *}$ & $.31^{* *}$ & $.37^{* * *}$ & $.42^{* *}$ & 1 & \\
\hline & (t) & 3.52 & 0.66 & $\begin{array}{c}-0.19 \\
\end{array}$ & 1.00 & $.34^{* *}$ & $.32^{* *}$ & $.27^{* *}$ & $.35^{* *}$ & $.45^{* *}$ & $.39^{* *}$ & $.40^{* *}$ & $.37^{* *}$ & $.36^{* *}$ & $.39^{* *}$ & $.33^{* *}$ & $.24^{* *}$ & $.31^{* *}$ & $.51^{* *}$ & $.48^{* *}$ & $.60^{* *}$ & $.56^{* *}$ & $.54^{* *}$ & $.45^{* *}$ & 1 \\
\hline
\end{tabular}

Note. Variable 1 - Digital literacy, Variable 2 - Learning strategy, Variable 3 - Core competency; (a) ability to use digital learning tools (b) managing digital learning platforms (c) ability to use advanced level digital tools (d) security and ethics (e) rehearsal (f) elaboration (g) organization (h) critical thinking (i) metacognitive self-regulation (i) time and study strategies (B) effort regulation (1) peer learning (IM) helping seeking (I) communication \& human relationship () expertise (P) creativity (d) self-directedness $(\mathrm{P}$ general job skills (S) international mindset (t) problem-solving ability and thinking 
As shown in Table 4, the scores for female college students were higher than those for male students in learning strategies, which was statistically significant at the .05 level. However, digital literacy and core competencies were not significant statistically. As shown in Table 5, four-year college students scored higher than two-year college students in learning strategies, which was statistically significant at the .05 level. However, again, digital literacy and core competencies were not significant statistically. The results of the analysis showed that there was no significant difference between the groups in terms of core competencies or digital literacy. However, female students and four-year college students showed a significant difference in terms of learning strategy compared with the male students and the two-year college students. However, the average difference was small, and so, it is likely that these groups will largely be regarded as homogeneous in this area.

Table 4. Group difference by gender

\begin{tabular}{lccccc}
\hline Variable & & $N$ & $M$ & $S D$ & \multirow{2}{*}{$t$ value } \\
\hline \multirow{2}{*}{ Digital literacy } & Male & 350 & 3.28 & 0.68 & \multirow{2}{*}{-0.58} \\
\cline { 2 - 5 } Learning strategies & Female & 566 & 3.38 & 0.63 & \multirow{2}{*}{$-2.39 *$} \\
\cline { 2 - 5 } Core competencies & Male & 350 & 4.55 & 0.72 & \multirow{2}{*}{-1.53} \\
\cline { 2 - 5 } & Female & 566 & 4.62 & 0.73 & 0.53 \\
\cline { 2 - 5 } & Male & 350 & 3.53 & 0.48 & \\
\cline { 2 - 5 } & Female & 566 & 3.55 & &
\end{tabular}

${ }^{*} p<.05$

Table 5. Group difference by four-year and two-year college students

\begin{tabular}{|c|c|c|c|c|c|}
\hline Variable & & $N$ & $M$ & $S D$ & $t$ value \\
\hline \multirow{2}{*}{ Digital literacy } & 4-year & 526 & 3.36 & 0.66 & \multirow{2}{*}{-0.85} \\
\hline & 2-year & 390 & 3.32 & 0.63 & \\
\hline \multirow{2}{*}{ Learning strategies } & 4-year & 526 & 4.64 & 0.73 & \multirow{2}{*}{$-2.12 *$} \\
\hline & 2-year & 390 & 4.54 & 0.71 & \\
\hline \multirow{2}{*}{ Core competencies } & 4-year & 526 & 3.55 & 0.50 & \multirow{2}{*}{0.12} \\
\hline & 2-year & 390 & 3.54 & 0.48 & \\
\hline
\end{tabular}

${ }^{*} p<.05$

\section{Testing the Measurement Model}

The measurement model was used to confirm that the latent variables were represented by observed variables, and then to assess the hypothesized structural model. Several indexes were calculated to evaluate the fit of the model to the data: chi-square $\left(\chi^{2} / d f<2.0\right.$ suggests a good fit), CFI $>.90$, the Tucker-Lewis index (TLI $>.90)$, GFI $>.90$, RMSEA $<.05$, and SRMR $<.05$. The measurement model showed good fit statistics for the latent variables, $\chi^{2}(157)=735.10, p=.001, \chi^{2} / d f=4.42, \mathrm{GFI}=.92$, SRMR $=.04, \mathrm{CFI}=.95$, TLI $=.94$ and RMSEA $=.06$ (Low $90=.06-$ High $90=.07$ ) (see Table 2). All standardized loadings on the variables were significant ( $p<.001$; range $.46-.87$ for each variable) supporting the construct validity of the scales. Construct validity may be further examined by using convergent validity with regard to a set of variables presumed to assess the same construct, and discriminant validity with regard to a set of variables presumed to measure different constructs (Kline, 2005). Convergent validity is assessed through the construct reliability and AVE of the factors in the measurement model. Theoretically, if the conceptual reliability is .70 or more and AVE is .50 or more, the validity of the measurement model is satisfactory (Yu, 
2012). As shown in Table 6, the reliability for each concept was .91 for digital literacy, .94 for learning strategy, and .93 for core competencies, respectively. In addition, AVE has a validity of the measurement model with .73 for digital literacy, .63 for learning strategy, and .64 for core competency.

Table 6. Confirmatory factor analysis of the measurement model

\begin{tabular}{|c|c|c|c|c|c|c|c|}
\hline $\begin{array}{l}\text { Latent } \\
\text { variable }\end{array}$ & Measured variable & $\begin{array}{l}\text { Unstandardized } \\
\text { estimate }\end{array}$ & $\begin{array}{l}\text { Standardized } \\
\text { estimate }\end{array}$ & $\begin{array}{l}\text { Standard } \\
\text { error }\end{array}$ & $t$ value & $\begin{array}{l}\text { Construct } \\
\text { Reliability }\end{array}$ & AVE \\
\hline \multirow{4}{*}{1} & $\begin{array}{l}\text { Ability to use digital learning } \\
\text { tools }\end{array}$ & 1.00 & .77 & - & - & \multirow{4}{*}{.91} & \multirow{4}{*}{.73} \\
\hline & $\begin{array}{l}\text { Managing digital learning } \\
\text { platforms }\end{array}$ & 1.27 & .87 & 0.05 & $23.42^{* * *}$ & & \\
\hline & $\begin{array}{l}\text { Ability to use advanced digital } \\
\text { tools }\end{array}$ & 1.05 & .77 & 0.05 & $19.83^{* * *}$ & & \\
\hline & Security and ethics & 1.08 & .72 & 0.05 & $20.79^{* * * *}$ & & \\
\hline \multirow{9}{*}{2} & Help seeking & 1.00 & .79 & - & - & \multirow{9}{*}{.94} & \multirow{9}{*}{.63} \\
\hline & Peer learning & 0.91 & .66 & 0.04 & $20.66^{* * *}$ & & \\
\hline & Effort regulation & 0.87 & .73 & 0.04 & $23.66^{* * *}$ & & \\
\hline & Time and study strategies & 0.93 & .85 & 0.03 & $28.45^{* * *}$ & & \\
\hline & Metacognitive self-regulation & 0.72 & .78 & 0.03 & $25.53^{* * *}$ & & \\
\hline & Critical thinking & 0.93 & .81 & 0.04 & $26.86^{* * *}$ & & \\
\hline & Organization & 1.02 & .83 & 0.04 & $27.84^{* * *}$ & & \\
\hline & Elaboration & 0.93 & .77 & 0.04 & $25.42^{* * * *}$ & & \\
\hline & Rehearsal & 0.71 & .71 & 0.03 & $20.91^{* * *}$ & & \\
\hline \multirow{7}{*}{3} & $\begin{array}{l}\text { Problem-solving ability and } \\
\text { thinking }\end{array}$ & 1.00 & .76 & - & - & \multirow{7}{*}{.93} & \multirow{7}{*}{.64} \\
\hline & International mindset & 0.96 & .56 & 0.06 & $16.23^{* * *}$ & & \\
\hline & General job skills & 1.01 & .75 & 0.05 & $21.90^{* * *}$ & & \\
\hline & Self-directedness & 1.04 & .75 & 0.05 & $21.80^{* * * *}$ & & \\
\hline & Creativity & 0.94 & .60 & 0.05 & $20.12^{* * * *}$ & & \\
\hline & Expertise & 1.07 & .76 & 0.05 & $20.26^{* * *}$ & & \\
\hline & $\begin{array}{l}\text { Communication \& human } \\
\text { relationship }\end{array}$ & 0.66 & .62 & 0.04 & $18.01^{* * *}$ & & \\
\hline
\end{tabular}

Note: Latent variable 1 - Digital literacy; Latent variable 2-Learning strategy; Latent variable 3 - Core competencies.

In terms of discriminant validity, if the AVE is greater than the squared correlation coefficient $(\varphi 2)$ between each latent factor at the bottom of the diagonal (Fornell \& Larcker, 1981; Yu, 2012). As shown in Table 7, the discriminant validity was significantly accepted.

Table 7. Discriminant validity

\begin{tabular}{lccc}
\hline Latent variable & Digital literacy & Learning strategy & Core competencies \\
\hline Digital literacy & $.73^{*}$ & & \\
\hline Learning strategy & $.17 \mathrm{c}$ & $.63^{*}$ & $.64^{*}$ \\
\hline Core competencies & $.18 \mathrm{c}$ & $.31 \mathrm{c}$ & \\
\hline
\end{tabular}

Note: $*=\mathrm{AVE}, \mathrm{c}=\varphi 2$ (squared correlation coefficient between latent variable), acceptance criteria: A.V.E $>\varphi 2$ 


\section{Testing the Structural Model}

The structural model showed good fit statistics for the latent variables: $\chi^{2}(157)=744.14, p=.001$, $\chi^{2} / d f=4.740, \mathrm{GFI}=.92, \mathrm{SRMR}=.05, \mathrm{CFI}=.95, \mathrm{TLI}=.94$, and RMSEA $=.06$ (Low $90.06-$ High 90.07 ). All pathways for this model were significantly positive as represented in Table 8 . The direct path coefficient from digital literacy to learning strategy was significant $(\beta=.44, p<.001)$, the direct path coefficient from digital literacy to core competencies was significant $(\beta=.26, p<.05)$, and the direct path coefficient from learning strategy to core competencies was significant $(\beta=.50, p<.001)$. Therefore, hypothesis 1 of this study was accepted in that it is significant to have the direct influence of digital literacy on core competencies. The proportion of explained variance for the model presented by squared multiple correlations (SMC) was $20 \%$ for learning strategies and $43 \%$ for core competencies (Kline, 2005).

Table 8. Coefficients of the Structural Model

\begin{tabular}{lccccc}
\hline \multicolumn{1}{c}{ Path } & $\begin{array}{c}\text { Unstandardized } \\
\text { estimate }\end{array}$ & $\begin{array}{c}\text { Standardized } \\
\text { estimate }\end{array}$ & Standardized errors & $t$ value & $S M C$ \\
\hline Digital literacy $\rightarrow$ Learning strategy & .58 & .44 & 0.05 & $12.01^{* * *}$ & .20 \\
\hline Digital literacy $\rightarrow$ Core competencies & .14 & .26 & 0.02 & $7.13^{* * *}$ \\
\hline Learning strategy $\rightarrow$ Core competencies & .21 & .50 & 0.02 & $12.42^{* * *}$ & .43 \\
\hline ****
\end{tabular}

*** $p<.001$.

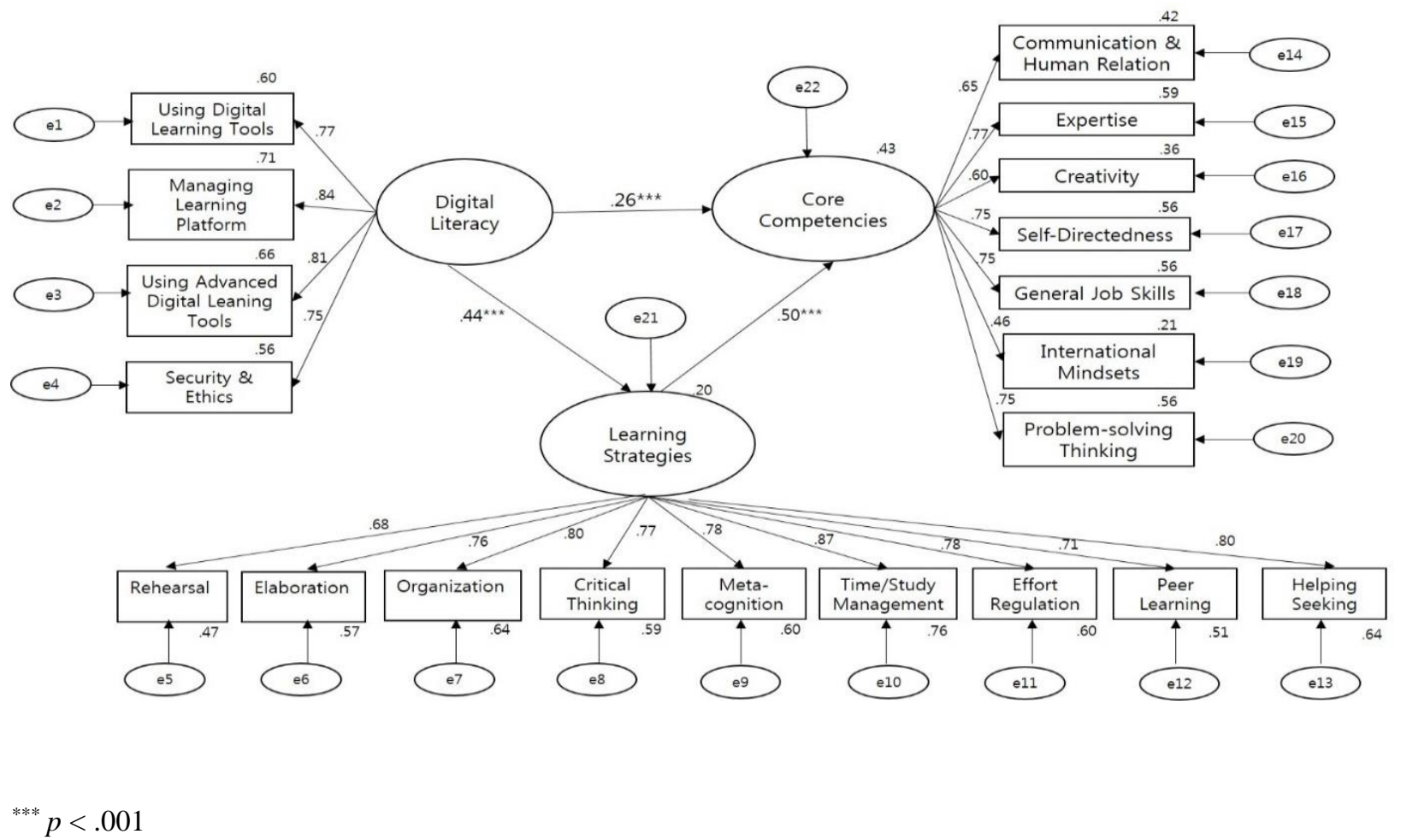

Figure 2. Indirect relationship between digital literacy, learning strategies, and core competencies

The direct and indirect effects between pathways are described in Table 9. The direct effect of digital literacy on core competencies was .26, the direct effect of digital literacy on learning strategies was .44, and the direct effect of learning strategies on core competencies was .50. In addition, the indirect effect of 
learning strategy on the relationship between core competencies and digital literacy was .21. In this respect, this study confirmed that digital literacy is a parameter that can enhance the effect of core competence when mediating learning strategy.

Table 9. Effect decomposition of the structural model

\begin{tabular}{lcccc}
\hline Independent variable & Dependent variable & Direct effect & Indirect effect & Total effect \\
\hline Digital literacy & Learning strategy & .44 & - & .44 \\
Digital literacy & Core competencies & .26 & .21 & .47 \\
Learning strategy & Core competencies & .50 & - & .50 \\
\hline
\end{tabular}

Bootstrapping was used to test for the significance of the mediation effect, as suggested by Shrout and Bolger (2002). Bootstrapping shows a confidence interval (CI) of $95 \%$ for the significance of mean indirect effect from the bootstrap results. If the $\mathrm{CI}$ does not include zero, then the indirect effect is considered statistically significant at .05 level. As showed in Table 10, bootstrapping analysis for the mediating effect of learning strategy on the relationship between digital literacy and core competencies $(b=.21 ; 95 \%$ CI: $.17 \sim .25$ ) were significant because 0 is not included in the range. Therefore, hypothesis 2 of this study was confirmed: Learning strategies have an indirect influence upon the relationship between digital literacy and core competencies that is significant.

Table 10. Bootstrapping for mediating effect test

\begin{tabular}{cccc}
\hline Pathway & Unstandardized $(b)$ & $S E$ & $\begin{array}{c}95 \% \text { CI } \\
\text { (bias-corrected) }\end{array}$ \\
\hline Digital literacy $\rightarrow$ learning strategy $\rightarrow$ core competencies & .210 & 0.02 & $.17 \sim .25^{* *}$ \\
\hline${ }^{* *} p<.01$ & & &
\end{tabular}

\section{Discussion}

This study examined the differences between these variables depending on individual characteristics, such as whether they are two-year or four-year college students, as well as gender. It also examined the structural relationship among digital literacy, learning strategies, and core competencies perceived by South Korean college students. This study identified no group differences in digital literacy and core competencies; however, learning strategies perceived by female and four-year college students were higher than male and two-year college students. It is significant that the results confirmed the group difference in learning strategies combined with major knowledge and learning performance in that admission scores and academic abilities were higher for four-year students than for two-year college students in Korea. Also, the results show that college students are homogeneous in digital literacy and core competencies irrespective of individual characteristics. In this respect, it is necessary to identify group differences for many variables such as achievement goal orientation, learning styles, and self-determined motivation related to college students in future research as well as to foster academic discussion about why there such group differences exist.

The results of the structural relationship showed that digital literacy had direct influence on core competencies; moreover, learning strategies mediated the influence. Digital literacy had a positive impact on core competencies (H2). This result demonstrated the findings of previous studies that using the digital technology and information may catalyze core competencies such as online information search strategies 
(Çoklar, Yaman, \& Yurdakul, 2017), problem-solving (Cerezo et al., 2010), teamwork and collaboration (Dabbagh \& Kinsantas, 2012; Järvelä \& Järvenoja, 2011; Lee \& Tsai, 2011). Moreover, this study identified that digital literacy was correlated with self-regulated learning skills (Green, Seung, \& Copeland, 2014; Yang \& Kim, 2014). Additionally, the study found that learning strategies are mediating variables that influence the impact of digital literacy on core competencies (H3). The results are consistent with some empirical findings. Bulu and Pederson (2012) argued that meta-cognition strategies play a facilitating role in problem-solving tasks in the hypermedia learning environment. Further, Prior, Mazanov, Meacheam, Heaslip, and Hanson (2016) reported that digital literacy has a significant effect on self-efficacy by facilitating online peer interaction based on learning platforms. Cheng and Chau (2013) maintained that using digital-based portfolios is more effective when college students go through cognitive and metacognitive strategies. Also, D'Souza (2013) found that mutual discussion and conversation with peers helps students develop core competencies through learning strategies.

These results provide implications for college education practices. First, colleges need to develop digital technology-enhanced tools and competency-driven teaching in order to enhance learning opportunities and make them meaningful to students. Mekovek, Anicic, and Arbanas (2018) showed that problem-based learning was able to develop core competencies of undergraduate IT students. Wurdinger and Qureshi (2015) found that project-based learning was a significant method for facilitating problem solving, self-direction, communication, and creative thinking. Lee (2017) maintained that the design thinking-based courses had an impact upon students' abilities to collaborate and solve problems. Additionally, colleges need to provide real learning experiences using Hologram, Virtual Reality, Augmented Reality, and 3D Printing. To illustrate, Sevillano-García and Vázquez-Cano (2015) demonstrated that digital mobile devices are able to foster core competencies in a higher education context. Cela-Ranilla, Esteve-Gonzalez, Esteve-Mon, and Gisbert-Cervera (2014) found that 3D simulations were effective for aiding students in acquiring the self-management skills. In this respect, colleges need to help college students develop core competencies by providing digital technology-enriched lectures and programs in which their digital literacy may confirm a preceding influencer of core competence.

This study also found a significant relationship between learning strategies and cognitive skills (Kesici, Sahin, \& Akturk, 2009), meta-cognitive skills (De Backer, Van Keer, \& Valcke, 2015), peer scaffolding and tutoring (Pifarre \& Cobos, 2010), and e-portfolios (Cheng \& Chau, 2013). These all contributed to the influence of digital literacy on students' core competencies. It suggests that college students need to use smart learning devices for efficient notes, summaries, peer learning, and critical thinking. Further, they need to share creative ideas, solve problems through social media, and learn to evaluate and provide critical assessment of their own work by using e-Portfolios. Additionally, college teachers should be required to utilize students as digital technology assistants or learning tutors similar to those of their peers by making use of a variety of learning strategies.

This study had some limitations, which gave rise to the following six suggestions for future research. First, this study implied that learning strategies facilitate digital literacy and core competencies. However, this study did not investigate the relationship between digital literacy and core competencies in terms of sub-variables of learning strategies. This analysis may be useful in developing personalized teaching and learning methods and learning resources such as textbooks and digital technologies in order to build a classroom environment in accordance with specific cognitive and meta-cognitive learning strategies and resource management learning strategies being utilized by college students in the classroom.

Second, while learning strategies are constituted by learning motivation and learning strategy (Prinrich et al., 1993), this study did not measure learning motivation strategies such as self-efficacy, 
intrinsic and extrinsic motivation, and test unrest. In future research, it will be necessary to measure the relationship between digital literacy and core competence in terms of learning motivation strategies. This study also analyzed the mediating effects of learning strategies in relation to digital literacy and core competencies. In future research, it is necessary to explore the contribution to the relationship between digital literacy and core competencies of learner characteristics such as achievement goal orientation, learning style, and academic self-efficacy.

Third, this study was oriented toward a correlational research design in order to facilitate the investigation of correlations and causality between variables. This design is significant because of its ability to confirm the relationship and effect between variables through empirical tests. However, in the context of teaching and learning at the college level, it is uncertain that core competencies can be improved through a variety of digital technologies such as SNS, social media, and web platforms. It was not verified that differences in digital literacy and core competencies resulted from college students' learning strategy profiles. Therefore, in future research, it is necessary to conduct experiments or quasi-experimental studies on the effect of learning activities using digital technologies such as holograms and AR on building and strengthening core competencies.

Fourth, it was not possible in this study to identify a difference in core competencies or digital literacy according to the demographic backgrounds and the learning strategy profiles of college students. It will be vital for future researchers to study the relationships between the variables and the path differences among the variables according not only to demographic information such as race, gender, and college type but also the learning strategy profile types.

Fifth, there is a need for conducting qualitative researches to derive the qualitative attributes and experiences of which and how college students are using digital technologies and learning strategies in the classroom and individual learning and how they are acting as learning tools and strategies to improve core competencies. Additionally, it is necessary to explore the success or barrier factors through qualitative case analysis, such as focus group interviews or behavioral event interviews of distinguished graduates exhibiting high digital literacy and core competencies. Specifically, it is necessary that subsequent researchers conduct action studies exploring how college students understand digital technology and tools as learning tools, how these tools are used in classrooms and personal learning, what advantages and disadvantages accompany their use, which specific learning strategies are effective, and how digital technologies and learning strategies affect core competencies.

Sixth, there is a lack of prior research and a wide inconsistency among academic scholars about digital literacy and core competency. Therefore, this study was limited in that it had a narrow body of prior research to draw from. Thus, it is inevitable that future studies will conduct in-depth logical and theoretical analyses of the causal relationship between two variables as well as the differences in the respective definitions, characteristics, and components of digital literacy and core competencies. To do this, it is necessary to conduct in-depth qualitative research through such methods as participation observation and grounded theory on how various factors of digital literacy are being utilized in classroom and individual learning.

In conclusion, this study reveals that digital literacy had direct influence on core competencies and, learning strategies mediated the relationship between digital literacy and core competencies. This suggests that college managers need to help college students develop digital literacy by providing digital technologyenriched lectures and programs because digital literacy may be confirmed a preceding influence of core competence. Further, it found that learning strategies may function as catalysts or triggers for developing core competencies such as creativity and critical thinking by using digital technologies and information 
during classroom and self-study time and may also facilitate collaborative learning with colleagues. Additionally, this study suggests that some future researchers should focus upon the following researches: The effects of cognitive, meta-cognitive, and resource management strategies on the relationship between digital literacy and core competencies; the contribution to the relationship between digital literacy and core competencies of learner characteristics such as achievement goal orientation, learning style, and academic self-efficacy; multiple group path analysis of the moderating effects between digital literacy and core competencies depending on college students' demographics; digital technology-enhanced, competencydriven teaching and learning from the perspective of learning strategies; and the mediation effect analysis using the MSLQ consisting of both motivation and learning strategies sections.

\section{References}

Adams, C. J. (2013). 'Soft skills' seen as key element for higher Ed many teens lack crucial life skills like resiliency, grit, and the ability to communicate and advocate, and that's hurting college-completion rates. Education Digest, 78, 18-22.

Ala-Mutka, K. (2011). Mapping digital competence: Towards a conceptual understanding. Retrieved Jan 26, 2016 from http://ftp.jrc.es/EURdoc/JRC67075_TN.pdf.

Alexiou, A., \& Paraskeva, F. (2010). Enhancing self-regulated learning skills through the implementation of an eportfolio tool. Procedia-Social and Behavioral Sciences, 2, 3048-3054. doi: 10.1016/j.sbspro.2010.03.463

Ausubel, D. P. (2000). The acquisition and retention of knowledge: A cognitive view. Boston: Kluwer Academic Publisher.

Azevedo, R. (2005). Computer environments as metacognitive tools for enhancing learning. Educational Psychologist, 40, 193-197.

Baek, P. G. (2013). A study on the relationship and characteristics between Korean Collegiate Essential Skills and Undergraduates' individual variant Factors. Korean Journal of General Education, 7, 349-387.

Billing, D. (2007). Teaching for transfer of core/key skills in higher education: Cognitive skills. Higher Education, 53, 483-516. doi: 10.1007/s10734-005-5628-5

Boyatzis, R. E. (2008). Competencies in the 21st century. Journal of Management Development, 27, 5-12. doi: $10.1108 / 02621710810840730$

Boyatzis, R. E. (2009). Competencies as a behavioral approach to emotional intelligence. Journal of Management Development, 28, 749-770. doi: 10.1108/0262171091 0987647

Boyatzis, R. E., \& Saatcioglu, A. (2008). A 20 -year view of trying to develop emotional, social and cognitive intelligence competencies in graduate management education. Journal of Management Development, 27, 92108. doi: 10.1108/026 21710810840785

Bulu, S. T., \& Pedersen, S. (2012). Supporting problem-solving performance in a hypermedia learning environment: The role of students' prior knowledge and metacognitive skills. Computers in Human Behavior, 28, 11621169. https://doi.org/10.1016/j.chb.2012.01.026

Calvani, A., Fini, A., Ranieri, M., \& Picci, P. (2012). Are young generations in secondary school digitally competent? A study on Italian teenagers. Computers \& Education, 58, 797-807. https://doi.org/10.1016/j.compedu.2011.10.004

Cartelli, A. (2010). Frameworks for digital competence assessment: Proposals, instruments, and evaluation. Retrieved April 62016 from http://proceedings.informingscience.org/InSITE2010/InSITE10p561-574 Cartelli 861.pdf

Cela-Ranilla, J. M., Esteve-Gonzalez, V., Esteve-Mon, F., \& Gisbert-Cervera, M. (2014). 3D simulation as a learning environment for acquiring the skill of self-management: An experience involving Spanish university students of Education. Journal of Educational Computing Research, 51, 295-309. https://doi.org/10. 2190/EC.51.3.b

Cerezo, R., Núñez, J. C., Rosário, P., Valle, A., Rodríguez, S., \& Bernardo, A. B. (2010). New media for the promotion of self-regulated learning in higher education. Psicothema, 22, 306-315.

Cheng, G., \& Chau, J. (2013). Exploring the relationship between students' self-regulated learning ability and their ePortfolio achievement. The Internet and Higher Education, 17, 9-15. https://doi.org/10.1016/j.iheduc.2012.09.005

Cho, K., \& Cho, M. H. (2013). Training of self-regulated learning skills on a social network system. Social Psychology of Education, 16, 617-634. https://doi.org/ 10. 1007/s11218-013-9229-3

Cicchetti, D. V. (1994). Guidelines, criteria, and rules of thumb for evaluating normed and standardized assessment instruments in psychology. Psychological Assessment, 6, 284-290. 
Çoklar, A. N., Yaman, N. D., \& Yurdakul, I. K. (2017). Information literacy and digital nativity as determinants of online information search strategies. Computers in Human Behavior, 70, 1-9. https://doi.org/10.1016/j.chb.2016.12.050

Dabbagh, N., \& Kitsantas, A. (2012). Personal Learning Environments, social media, and self-regulated learning: A natural formula for connecting formal and informal learning. The Internet and higher education, 15, 3-8. https://doi.org/10.1016/ j.iheduc.2011.06.002

Davies, J. (2012). Facework on Facebook as a new literacy practice. Computers \& Education, 59, 19-29. https://doi.org/10.1016/j.compedu.2011.11.007

Davies, R. S. (2011). Understanding technology literacy: A framework for evaluating educational technology integration. TechTrends, 55, 45-52. https://doi.org/ 10.1007/ s11528-011-0527-3

De Backer, L., Van Keer, H., \& Valcke, M. (2012). Exploring the potential impact of reciprocal peer tutoring on higher education students' metacognitive knowledge and regulation. Instructional science, 40, 559-588. https://doi.org/10.1007/ s11251-011-9190-5

D’Souza, C. (2013). Debating: A catalyst to enhance learning skills and competencies. Education+Training, 55, 538549. https://doi.org/10.1108/ET-10-2011-0097

English, M. C., \& Kitsantas, A. (2013). Supporting student self-regulated learning in problem-and project-based learning. Interdisciplinary Journal of Problem-Based Learning, 7, 128-150. https://doi.org/10.7771/15415015.1339

Etikan, I., Musa, S. A., \& Alkassim, R. S. (2016). Comparison of convenience sampling and purposive sampling. American Journal of Theoretical and Applied Statistics, 5, 1-4.

Farrokhi, F., \& Mahmoudi-Hamidabad, A. (2012). Rethinking convenience sampling: Defining quality criteria. Theory and practice in language studies, 2, 784 - 792. doi:10.4304/tpls.2.4.784-792.

Ferrari, A. (2012). Digital competence in practice: An analysis of frameworks. Retrieved Jan 262015 from http://jiscdesignstudio.pbworks.com/w/file/fetch /55823162/ FinalCSReport_PDFPARAWEB.pdf

Fornell, C., \& Lacker. D. F. (1981). Evaluating structural evaluations model with unobservable variables and measurement error. Journal of Marketing Research, 18, 39-50. https://doi.org/10.1177/002224378101800104

Fraenkel, J. R., Wallen, N. E., \& Hyun, H. H. (1993). How to design and evaluate research in education (Vol. 7). New York: McGraw-Hill.

Gallardo-Echenique, E. E., Oliveira, J. M., Marqués, L., \& Esteve-Mon, F. (2015). Digital competence in the knowledge society. Journal of Online Learning and Teaching, 11, 1-16.

Gardner, H., \& Davis, K. (2013). The app generation: How today's youth navigate identity, intimacy, and imagination in a digital world. Yale University Press.

Garner, P. W. (2010). Emotional Competence and its Influences on Teaching and Learning. Educational Psychology Review, 22, 297-321. https://doi.org/10.1007/ s10648-010-9129-4

Garcia, T., \& Pintrich, P. R. (1996). The effects of autonomy on motivation and performance in the college classroom. Contemporary Educational Psychology, 21, 477-486. https://doi.org/10.1006/ceps.1996.0032

George, D., \& Mallery, P. (2003). SPSS for Windows step by step: A simple guide and reference. 11.0 update (4th ed.). Boston: Allyn \& Bacon.

Greene, J. A., Seung, B. Y., \& Copeland, D. Z. (2014). Measuring critical components of digital literacy and their $\begin{array}{llll}\text { relationships with learning. Computers \& Education, } & \text { 76, }\end{array}$ https://doi.org/10.1016/j.compedu.2014.03.008

Hatlevik, O. E., \& Christophersen, K. A. (2013). Digital competence at the beginning of upper secondary school: Identifying factors explaining digital inclusion. Computers \& Education, 63, 240-247. https://doi.org/10.1016/ j.compedu.2012.11.015

Hong, A., Jo, Y., \& Park, C. (2015). Exploration of college students' characteristics on NCS basic vocational competencies. Korean Journal of Educational Research, 53, 389-417.

Howland, J. L., Jonassen, D. H., \& Marra, R. M. (2012). Meaningful learning with technology (4th ed.). Upper Saddle River, NJ: Pearson.

International Society for Technology in Education. (2007). National educational technology standards for students. Eugene, OR: Author.

Järvelä, S., \& Järvenoja, H. (2011). Socially constructed self-regulated learning and motivation regulation in collaborative learning groups. Teachers College Record, 113, 350-374.

Jiménez-Cortés, R., Vico-Bosch, A., \& Rebollo-Catalán, A. (2017). Female university student's ICT learning strategies and their influence on digital competence. International Journal of Educational Technology in Higher Education, 14, 1-12. https://doi.org/10.1186/s41239-017-0040-7 
Jonassen, D. H. (1999). Designing constructivist learning environments. In C. M. Reigeluth (Eds.), Instructional design theories and models, Vol. II: A new paradigm of instructional theory. Mahwah, NJ: Lawrence Erlbaum Associates.

Kang, M., Kim, E. Yoo, Y. R., \& Kim, B. (2014). Comparing the life core competency of Korean undergraduates by learners characteristics. Journal of Lifelong Learning Society, 10, 61-84.

Kauffman, D. F., Zhao, R., \& Yang, Y. S. (2011). Effects of online note taking formats and self-monitoring prompts on learning from online text: Using technology to enhance self-regulated learning. Contemporary Educational Psychology, 36, 313-322. https://doi.org/10.1016/j.cedpsych.2011.04.001

Kesici, S., Sahin, I., \& Akturk, A. O. (2009). Analysis of cognitive learning strategies and computer attitudes, according to college students' gender and locus of control. Computers in Human Behaviour, 25, 529-534. https://doi.org/10.1016/ j.chb.2008.11.004

Kim, Y., Chung, J., Lee, C., \& Yi, Y. (2010). An analysis on undergraduate students' perception of core competencies and educational needs. Korea Educational Methodology Studies, 22, 1-20.

Kline, R. B. (2005). Principles and practice of structural equation modeling (2nd ed.). New York: Guilford Press.

Knight, S. (2011). Digital literacy can boost employability and improve student experience. Retrieved March 5, 2018 from https://www. theguardian.com/higher-education-network/blog/2011/dec/15/digital-literacyemployability-student-experience.

Koltay, T. (2011). The media and the literacies: Media literacy, information literacy, digital literacy. Media, Culture \& Society, 33, 211-221. https://doi.org/10. 1177/0163443710393382

Lee, J. (2015). College students' use of learning strategies and its relationship with academic achievement. Journal of the Korean Data Analysis Society, 17, 2163-2178.

Lee, M. (2017). A study on the effect of a design thinking-based course on enhancing university students" integrative competencies. Korea Science \& Art Forum, 28, 195-206.

Lee, A., \& Choi, M. (2014). Analysis of the research trend on the college students' key competecies and diagnosis tools. Journal of Educational Technology, 30, 561-588.

Lee, S. W. Y., \& Tsai, C. C. (2011). Students' perceptions of collaboration, self-regulated learning, and information seeking in the context of Internet-based learning and traditional learning. Computers in Human Behavior, 27, 905-914. https://doi.org/ 10. 1016/j.chb.2010.11.016

Liu, C. C., Cheng, Y. B., \& Huang, C. W. (2011). The effect of simulation games on the learning of computational problem solving. Computers \& Education, 57, 1907-1918. https://doi.org/10.1016/j.compedu.2011.04.002

Magno, C. (2010). The role of metacognitive skills in developing critical thinking. Metacognitive Learning, 5, $137-$ 156. https://doi.org/10.1007/s11409-010-9054-4

Martin, A., \& Grudziecki, J. (2006). DigEuLit: concepts and tools for digital literacy development. Innovation in Teaching and Learning in Information and Computer Sciences, 5, 1-19. https://doi.org/10.11120/ital.2006.05040249

Mekovek, R., Anicic, K. P., \& Arbanas, K. (2018). Developing undergraduate IT students' generic competencies through problem-based learning. TEM Journal, 7, 193-200.

Ministry of Science and ICT (2017). Sharing and spreading university software education innovation model. http://www.msit.go.kr/web/msipContents/contentsView.do? cateId=mssw315 \&artI d =1323719

Nunnally, J. C., \& Bernstein, I. H. (1994). Psychometric theory (3rd Ed.). New York: McGraw-Hill.

Pifarre, M., \& Cobos, R. (2010). Promoting metacognitive skills through peer scaffolding in a CSCL environment. Computer-Supported Collaborative Learning, 5, 237-253. https://doi.org/10.1007/s11412-010-9084-6

Pintrich, P. R., Smith, D. A., García, T., \& McKeachie, W. J. (1993). Reliability and predictive validity of the Motivated Strategies for Learning Questionnaire (MSLQ). Educational and Psychological Measurement, 53, 801-813. https://doi. org/10.1177/0013164493053003024

Pintrich, P. R., Smith, D. A., García, T., \& McKeachie, W. J. (1991). A manual for the use of the Motivated Strategies for Learning Questionnaire (MSLQ). Retrieved June 23, 2018 from https://eric.ed.gov/?id=ED338122

Pirzada, K., \& Khan, F. N. (2013). Measuring relationship between digital skills and employability. European Journal of Business and Management, 5, 124-133.

Prior, D. D., Mazanov, J., Meacheam, D., Heaslip, G., \& Hanson, J. (2016). Attitude, digital literacy and self-efficacy: Flow-on effect for online learning behavior. Internet and Higher Education, 29, 91-97. doi: 10.1016/j.iheduc.2016.01.001

Ryan, S. D., Magro, M. J., \& Sharp, J. H. (2011). Exploring educational and cultural adaptation through social networking sites. Journal of Information Technology Education, 10, 1-16.

Schunk, D. H. (2004). Learning theories: An educational perspective (4th ed.). New York: Prentice Hall.

Schwab, K. (2016). The fourth industrial revolution. Geneva, Switzerland: World Economic Forum. 
Shrout, P. E., \& Bolger, N. (2002). Mediation in experimental and nonexperimental studies: New procedures and recommendations. Psychological Methods, 7, 422- 445.

Sevillano-García, M. L., \& Vázquez-Cano, E. (2015). The Impact of Digital Mobile Devices in Higher Education. Educational Technology \& Society, 18, 106-118.

Solomon, G., \& Schrum, L. (2007). Web 2.0: New tools, new schools. Eugene, OR: International Society for Technology in Education.

Sozdamar-Keskin, N., Ozata, F. Z., Banar, K., \& Royle, K. (2015). Examining digital literacy competences and learning habits of open and distance learners. Contemporary Educational Technology, 6, 74-90.

Tariq, V. N., Scott, E. M., Cochrane, A. C., Lee, M., \& Ryles, L. (2004). Auditing and mapping key skills within university curricula. Quality Assurance in Education, 12, 70-81. https://doi.org/10.1108/09684880410536440

The Ministry of Education (2018). Leading innovative university to the Fourth Industrial Revolution. Retrieved March 5, 2018 from http://www.moe.go.kr/boardCnts/view.doboardID=294\&boardSeq=73088\&lev $=0 \&$ searchType $=$ null\&status $Y N=C \& p a g e=8 \& s=$ moe $\& m=0503 \&$ op Type $=N$

Vrana, R. (2016, October). Digital literacy as a boost factor in employability of students. In European Conference on Information Literacy (pp. 169-178). Springer, Cham.

Wang, N., Young, T., Wihite, S. C., \& Marczykm, G. (2011). Assessing students' emotional competence in higher education: Development and validation of the Widener Emotional Learning Scale. Journal of Psychoeducational Assessment, 29, 47-62. https://doi.org/10.1177/0734282909359394

Whitston, K. (1998). Key skills and curriculum reform. Studies in higher Education, 23, 307-319. https://doi.org/10.1080/03075079812331380276

Wood, M. J., \& Brink, P. J. (1998). Correlational designs. Advanced design in nursing research (2nd ed.). Thousand Oaks, CA: Sage Publications.

Wu, J. Y. (2015). University students' motivated attention and use of regulation strategies on social media. Computers \& Education, 89, 75-90. https://doi.org/10.1016/ j.compedu. 2015. 08.016

Wurdinger, S., \& Qureshi, M. (2015). Enhancing college students' life skills through project-based learning. Innovative Higher Education, 40, 279-286. doi:10.1007/ s10755-014-9314-3

$\mathrm{Yu}, \mathrm{J} . \mathrm{P}$. (2012). Concepts and understanding of structural equation modeling. Seoul: Hannare. 